\title{
PENGARUH JENIS DAN KONSENTRASI DAGING IKAN TERHADAP PENGEMBANGAN VOLUMETRIK, KERENYAHAN DAN RASA KERUPUK IKAN
}

\author{
Rosmawaty Peranginangin"), Soewarno T. Soekarto ${ }^{* *}$, \\ Lavlinesia ${ }^{* * * ;}$ dan Ijah Muljanah")
}

\begin{abstract}
ABSTRAK
Penelitian kerupuk dengan menggunakan 3 jenis ikan yaitu ikan remang (Congresox talabon), ikan kakap (Lates calcarifer) dan ikan belida (Notopterus cbilatus) dengan formulasi $0 ; 25 ; 40$ dan $50 \%$ telah dilakukan dengan tujuan untuk mengetahui pengaruhnya dalam pengembangan volumetrik, kerenyahan dan rasa krupuk. Hasil penelitian memperlihatkan bahwa jenis dan persentase ikan berpengaruh nyata terhadap volume pengembangan, kerenyahan dan rasa kerupuk. Ikan remang dengan persentase $25 \%$ memberikan volume pengembangan dan nilai kerenyahan tertinggi dibandingkan dengan ikan kakap dan ikan belida pada persentase ikan yang sama dan tidak jauh berbeda dengan kontrol. Peningkatan persentase ikan menjadi $40 \%$ dan $50 \%$ menurunkan volume pengembangan dan kerenyahan tetapi meningkatkan rasa kerupuk.
\end{abstract}

ABSTRACT: Effect of Species and Concentration of Fish Meat on the Volumetric Expansion, Crispiness and Taste of Fish Crackers. By: Rosmewaty Peranginangin, Soewarno T. Soekarto, Lavlinesia and Ijab Muljanab.

An experiment on effect of species and concentration of fish meat on the volumetric expansion, crispiness and taste of the fish crackers has been carried out. Meat of three fish species i.e. yellow pike conger (Congresox talabon), red snapper (Lates calcarifer) and featherback (Notopterus chilatus) at level of $0 ; 25 ; 40$ and $50 \%$ were used. The result showed that fish meat concentration significantly influence the volumetric expansion , crispiness and taste of fish crackers. Yellow pike conger meat showed the highest volumetric expansion compared to red snapper and featherback meats at the same concentration of $25 \%$. Increasing to 40 or $50 \%$ of fish meat concentration decreases volumetric expansion and crispiness but increases fish taste.

KEYWORDS: Volumetric expansion, crispiness, taste, fis b crackers

\section{PENDAHULUAN}

Kerupuk adalah sejenis makanan kecil yang mengalami pengembangan volume membentuk produk yang porous dan mempunyai densitas rendah selama penggorengan. Pengembangan volume dan kerenyahan merupakan faktor mutu kerupuk yang mempengaruhi penerimaan konsumen. Bahan baku utama yang digunakan dalam pembuatan kerupuk adalah karbohidrat. Sumber pati yang digunakan mempengaruhi daya kembang kerupuk (Matz, 1984). Daya kembang kerupuk dipengaruhi oleh proses gelatinisasi yang berbeda-beda

*) Peneliti pada Balai Penelitian Perikanan Laut, Jakarta

*) Pengajar pada Jurusan Teknologi Pangan dan Gizi, IPB Bogor

**) Mahasiswa Pascasarjana (S2) Jurusan Teknologi Pangan, IPB Bogor 
menurut sumber pati (karbohidrat) yang digunakannya. Pati sagu dan tapioka menghasilkan daya kembang yang paling tinggi dibandingkan dengan sumber pati lainnya (Cecil et al., 1982). Gelatinisasi adalah proses pengembangan granula pati yang terjadi pada pengukusan adonan. Proses gelatinisasi ini akan membentuk struktur elastis yang dapat mengembang pada penggorengan. Pati yang tergelatinisasi dengan baik akan menghasilkan volume pengembangan kerupuk yang baik. Dalam penelitian ini digunakan sagu sebagai sumber karbohidrat mengingat bahan ini belum dimanfaatkan secara optimal sedangkan potensinya cukup tinggi di Indonesia.

Pengembangan kerupuk juga dipengaruhi oleh komposisi bahan. Kandungan protein yang tinggi cenderung menurunkan daya kembang kerupuk. Selain jumlah protein juga sumber protein yang berbeda juga berpengaruh terhadap daya kembang kerupuk (Yu et al., 1981). Pengembangan kerupuk setelah digoreng sangat ditentukan oleh kandungan air yang terikat pada kerupuk sebelum digoreng. Pengeringan sebaiknya dilakukan sampai kadar air tertentu, agar dihasilkan tekanan uap yang maksimum pada proses penggorengan, sehingga gel pati bisa mengembang. Menurut hasil penelitian Soekarto dan Muliawan (1991) pengeringan sebaiknya dilakukan sampai kadar air 9 persen.

Dalam pembuatan kerupuk ditambahkan juga bahan penambah cita rasa seperti protein, lemak, gula dan bahan yang menimbulkan rasa gurih. Ikan yang sering digunakan untuk bahan tambahan dalam pembuatan kerupuk adalah ikan belida (Notopterus chilatus), ikan gabus (Opbiocephalus micropeltis), ikan kakap (Lates calcarifer), ikan tenggiri (Scomberomorous commersonii), dan ikan jambal roti (Arius thalassinus). Jenis ikan yang digunakan ternyata juga mempengaruhi kualitas kerupuk yang dihasilkan. Ikan belida mempunyai daging yang berwarna putih dan sangat lunak sehingga menghasilkan kerupuk dengan kualitas tinggi, berwarna putih dan tidak berbau amis. Jika ikan gabus yang digunakan dalam pembuatan kerupuk maka kerupuk yang dihasilkan tidak terlalu bagus disebabkan karena dagingnya yang sukar dihancurkan (Wiriano, 1984).

Dalam penelitian ini diteliti pengaruh jenis ikan belida (Notopterus chilatus), ikan kakap (Lates calcarifer) dan ikan remang (Congresox talabon) serta konsentrasi penambahan daging ikan kedalam tepung sagu terhadap volume pengembangan, kerenyahan dan rasa kerupuk.

\section{BAHAN DAN METODE}

\section{Bahan}

Bahan yang digunakan untuk membuat adonan kerupuk adalah tepung sagu (Metroxylon $s p$ ), ikan kakap, ikan belida, ikan remang, garam dan minyak goreng. Tepung sagu diperoleh dari industri pengolahan sagu di desa Tanah Baru, Kecamatan Kedung Halang, Bogor. Ikan kakap dan ikan remang diper- 
oleh dari Indramayu, ikan belida dari tempat pendaratan ikan Angso Duo Jambi. Ikan tersebut dimasukkan dalam peti berinsulasi kemudian diberi hancuran es lalu dibawa ke Laboratorium Instalasi Balai Penelitian Perikanan Laut Slipi, Jakarta.

\section{Metode}

Ikan dicuci, dibuang isi perut dan difilet untuk diambil dagingnya sebagai bahan tambahan dalam pembuatan kerupuk dengan konsentrasi yaitu: $0 \%$; $25 \% ; 40 \%$ dan $50 \%$. Pembentukan adonan diawali dengan memasak $30 \%$ tepung sagu dicampur dengan air (1:3). Adonan tersebut kemudian digunakan sebagai perekat (biang). Pati yang sudah tergelatinisasi (biang) tersebut dicampur dengan daging ikan lumat dan sisa tepung sagu sedikit demi sedikit sambil diaduk sehingga merata. Adonan dibentuk lembaran dengan ketebalan $3 \mathbf{~ m m}$ yang kemudian diletakkan di atas para bambu untuk dikukus selama 10 menit dengan suhu $90^{\circ} \mathrm{C}$. Kerupuk yang telah dikukus dikering-anginkan selama 5 menit, kemudian dilakukan pemotongan berbentuk persegi empat. Pengeringan dilakukan di bawah sinar matahari selama 12 jam sampai kadar air 9-10 persen dengan mengukur kadar airnya. Agar kadar air stabil kerupuk disimpan dalam desikator yang berisi larutan jenuh magnesium khlorida sampai berat kerupuk konstan. Penggorengan kerupuk menggunakan 0,5 1 minyak goreng untuk 12 gram kerupuk mentah pada suhu $170^{\circ}-180^{\circ} \mathrm{C}$.

\section{Pengamatan}

Pengamatan untuk ketiga jenis ikan dan kerupuk mentah adalah protein dengan metode Kjeldahl, lemak dengan metode Soxhlet (AOAC, 1984) dan kadar air dengan pengeringan dalam oven bersuhu $105^{\circ} \mathrm{C}$. Untuk kerupuk mentah ditentukan volume kerupuk dengan metode Zulviani (1992). Terhadap kerupuk goreng dilakukan pengamatan terhadap volume pengembangan kerupuk, uji organoleptik secara rating dan peringkat terhadap kerenyahan dan uji rasa ikan dilakukan secara rangsangan tunggal (single stimulus) (Soekarto, 1985)

Volume kerupuk diukur menggunakan alat manik-manik, wadah gelas, gelas ukur dan neraca analitik. Setiap pengukuran digunakan 6 keping kerupuk dengan berat sekitar $12 \mathrm{gram} / \mathrm{keping}$. Contoh dimasukkan dengan posisi vertikal dalam wadah gelas yang $1 / 4$ bagiannya telah diisi manik-manik. Wadah gelas kemudian diisi penuh dengan manik-manik sampai permukaan rata. Selanjutnya volume manik-manik yang digunakan baik tanpa atau dengan contoh diukur dengan gelas ukur. Volume jenis kerupuk ditentukan dengan rumus:

di mana:

\section{Volume jemic kerupuk - VI}

$\mathrm{V} 1$ = volume manik-manik dalam wadah gelas tampa berisi contoh

$\mathrm{V} 2$ = volume manik-manik dalam wadah gelas berisi contoh 
Selisih volume kerupuk goreng dengan volume jenis kerupuk mentah merupakan volume pengembangan kerupuk yang dihitung berdasarkan rumus sebagai berikut:

$$
\text { Volume pengembangan (\%) }=\frac{V g-V m}{V m} \times 100 \%
$$

di mana:

$\begin{array}{ll}\mathrm{Vg} & =\text { volume kerupuk goreng } \\ \mathrm{Vm} & =\text { volume kerupuk mentah }\end{array}$

Rancangan percobaan yang digunakan dalam penelitian ini adalah Rancangan Acak Lengkap Faktorial $(4 \times 3)$ dengan dua kali ulangan dan dilanjutkan dengan uji BNT.

\section{HASIL DAN PEMBAHASAN}

\section{Komposisi Proksimat Ikan}

Hasil analisis proksimat bahan segar ikan disajikan pada Table 1. Kadar protein ikan yang paling tinggi adalah ikan kakap $(20,71 \%)$, kemudian ikan belida $(19,04 \%)$ dan ikan remang $(17,83 \%)$. Kadar lemak ikan yang paling tinggi adalah ikan belida $(1,84 \%)$ disusul oleh ikan kakap $(1,01 \%)$ dan paling rendah adalah ikan remang $(0,86 \%)$.

Table 1. Chemical composition of fresh fish

\begin{tabular}{lccc}
\hline \multicolumn{1}{c}{ Fish species } & Moisture (\%) & Fat (\%) & Protein (\%) \\
\hline 1. Yellow pike conger & 79.98 & 0.86 & 17.83 \\
2. Red snapper & 77.45 & 1.01 & 20.71 \\
3. Featherback & 78.06 & 1.84 & 19.04 \\
\hline \hline
\end{tabular}

\section{Komposisi Proksimat Kerupuk Mentah}

Hasil analisis kadar protein dan lemak kerupuk mentah disajikan pada Table 2. Ikan yang mengandung lemak dan protein lebih tinggi menghasilkan kerupuk mentah dengan kandungan lemak dan protein yang juga tinggi, begitu juga dengan peningkatan jumlah ikan yang ditambahkan akan meningkatkan kandungan protein dan lemak kerupuk. 
Table 2. Chemical composition of fisb crackers

\begin{tabular}{lccc}
\hline \multicolumn{1}{c}{ Fisb species } & Fisb persentage & Protein (\%) & Fat (\%) \\
\hline Control & 0 & 0.78 & 0.04 \\
Yellow pike conger & 25 & 5.08 & 0.24 \\
& 40 & 8.13 & 0.38 \\
& 50 & 9.38 & 0.47 \\
Red snapper & 25 & 5.87 & 0.27 \\
& 40 & 9.38 & 0.46 \\
& 50 & 11.44 & 0.59 \\
Featberback & 25 & 5.48 & 0.48 \\
& 40 & 8.44 & 0.76 \\
& 50 & 10.49 & 0.94 \\
\hline \hline
\end{tabular}

\section{Sifat Adonan}

Pengamatan adonan yang dilakukan secara visual terlihat bahwa jenis ikan dan persentase ikan dalam formulasi memberikan perbedaan terhadap sifat adonan. Perbedaan sifat adonan terlihat dalam bentuk mudah tidaknya adonan menyatu pada akhir proses pengadukan (mixing) dan sifat mudah lengketnya adonan sewaktu dibentuk lembaran pada plastik. Secara umum salah satu tanda proses pengadukan adonan sudah selesai adalah apabila adonan sudah menyatu dan tidak lengket.

Meningkatnya jumlah penambahan ikan dalam adonan menyebabkan adonan sulit menyatu. Hal ini disebabkan karena semakin tinggi jumlah ikan yang ditambahkan, jumlah tepung yang dimasak sebagai biang dikurangi untuk mendapatkan adonan yang lebih kompak. Adonan yang paling sulit menyatu adalah ikan kakap yang diperkirakan karena sifat jaringan otot dagingnya lebih kasar dibandingkan dengan ikan remang dan belida.

\section{Sifat Kerupuk Mentah}

Kerupuk ikan mentah yang diperoleh dari hasil penjemuran di bawah sinar matahari selama 6 jam pada keadaan cerah mempunyai warna kuning kecoklatan yang disebabkan oleh warna sagu yang digunakan. Sagu mempunyai derajat putih yang lebih rendah dari tepung tapioka yang banyak digunakan untuk pembuatan kerupuk ikan. Rendahnya derajat putih tepung sagu karena pada tepung sagu terdapat senyawa fenolik (tanin) yang pada waktu proses ekstraksi terjadi reaksi pencoklatan oleh enzim fenolase dan oksigen membentuk polimer hidroksi quinon yang berwarna coklat. Selain itu selama proses pengukusan terjadi reaksi Maillard yang disebabkan oleh reaksi karbohidrat 
khususnya gula pereduksi dengan gugus amino primer melalui reaksi Amadori dan kondensasi aldol membentuk senyawa melanoidin.

\section{Sifat Kerupuk Goreng}

Kerupuk dikatakan tidak mengembang jika sebagian atau seluruh kerupuk tidak mengembang selama penggorengan sehingga dihasilkan kerupuk goreng yang keras sebagian atau seluruhnya. Lamanya waktu proses penggorengan kerupuk ikan sekitar 7-10 detik yang ditandai dengan berubahnya warna kerupuk menjadi putih pada bagian yang mengembang. Karakteristik fisik kerupuk ikan goreng disajikan pada Table 3.

Table 3. Physical characteristics of fried fish crackers

\begin{tabular}{lll}
\hline \hline \multicolumn{1}{c}{ Fisb species } & Colour & \multicolumn{1}{c}{ Bubbles } \\
\hline 1. Yellow pike conger & white & small, evenly distributed \\
2. Featherback & white & smaller, evenly distributed \\
3. Red snapper & yellow & sligbtly bigger, unevenly distributed \\
\hline \hline
\end{tabular}

Kerupuk goreng yang dibuat dari ikan remang dan belida tidak banyak berbeda dalam hal warna dan besarnya gelembung. Hal ini disebabkan karena jaringan otot daging ikan belida dan remang sangat halus dan mudah dihancurkan. Berbeda halnya dengan ikan kakap yang jaringan otot dagingnya kasar sehingga kerupuk yang dihasilkan juga berbeda mutunya. Warna kerupuk goreng yang dibuat dari ikan belida dan remang berwarna putih sedangkan yang dari ikan kakap berwarna kuning. $\mathrm{Hal}$ ini disebabkan karena kurang mengembangnya kerupuk ikan kakap dibandingkan dengan kerupuk belida dan remang. Cerahnya warna kerupuk goreng yang mengembang disebabkan karena terjadinya perenggangan misela dan pengembangan granula sel.

\section{Pengembangan Volume Kerupuk}

Pengembangan volume kerupuk tanpa ikan adalah $374 \%$. Makin tinggi penambahan daging ikan maka volume pengembangan kerupuk semakin rendah. Nilai rata-rata persentase volume pengembangan kerupuk disajikan pada Table 4. Ikan remang mempunyai volume pengembangan tertinggi, diikuti oleh ikan kakap dan ikan belida. Pengaruh jenis ikan terhadap volume pengembangan kerupuk dipengaruhi oleh kandungan lemak ikan. Semakin tinggi kandungan lemak semakin rendah pengembangan volume kerupuk. Adanya lemak dalam adonan dapat mengganggu proses gelatinisasi karena lemak membentuk suatu lapisan lemak pada permukaan granula yang menyebabkan penetrasi air terganggu. Demikian juga lemak akan membentuk 
kompleks dengan amilosa yang menghambat pengikat air oleh pati dan mempengaruhi proses gelatinisasi (Hodge dan Osman, 1976). Selain lemak, protein juga sangat berpengaruh terhadap volume pengembangan kerupuk (Yu, 1991). Dari hasil penelitian ini terlihat bahwa semakin tinggi penambahan daging maka volume pengembangan semakin rendah.

Table 4. Mean value of volumetric expansion of fried fish crackers

\begin{tabular}{lcccc}
\hline \hline \multirow{2}{*}{ Fisb species } & \multicolumn{4}{c}{ Percentage } \\
\cline { 2 - 5 } & 0 & 25 & 40 & 50 \\
\hline 1. Control & 374 & - & - & - \\
2. Yellow pike conger & - & 308 & 281 & 252 \\
3. Red snapper & - & 236 & 216 & 203 \\
4. Featherback & - & 184 & 150 & 145 \\
\hline \hline
\end{tabular}

\section{Kerenyahan Kerupuk Ikan}

Kerenyahan kerupuk goreng meningkat sejalan dengan meningkatnya volume pengembangan kerupuk goreng (Muliawan, 1991). Dari hasil penelitian (Table 5) ternyata bahwa kerenyahan kerupuk goreng tidak seluruhnya dipengaruhi oleh volume pengembangan kerupuk. Volume pengembangan ikan belida lebih rendah $(213 \%)$ dari pada ikan kakap $(257 \%)$ tetapi kerenyahan kerupuk belida $(5,4)$ lebih tinggi dari kerupuk kakap $(4,0)$. Hal ini diduga karena kandungan protein ikan kakap lebih tinggi dibandingkan dari protein ikan belida. Sedangkan kandungan lemak ikan belida lebih tinggi dari ikan kakap yang menyebabkan kerupuk belida lebih renyah daripada kerupuk kakap.

Table 5. Mean value of volumetric expansion and crispiness of fish crackers added with $25 \%$ fish meat

\begin{tabular}{lcc}
\hline \multicolumn{1}{c}{ Fisb species } & Volumetric expansion (\%) & Crispiness \\
\hline 1. Control & $374^{a}$ & $7.0^{a}$ \\
2. Yellow pike conger & $304^{b}$ & $6.9^{a}$ \\
3. Red snapper & $257^{c}$ & $4.0^{b}$ \\
4. Featberback & $213^{d}$ & $5.4_{c}$ \\
\hline \hline
\end{tabular}

Note: The same notation indicates statistically not different $(P>0.05)$ 
Kerenyahan kerupuk secara rating dapat dipertajam oleh data hasil pengamatan kerenyahan kerupuk secara peringkat. Perhitungan data hasil secara peringkat dihitung secara komposit yang disajikan pada Table 6. Berdasarkan skor yang diperoleh maka urutan kerenyahan kerupuk goreng yang paling tinggi dimulai dari kerupuk tanpa ikan (kontrol), kerupuk ikan remang, kerupuk ikan belida dan kerupuk ikan kakap.

Table 6. Ranking test of crackers crispiness added with $25 \%$ fish meat

\begin{tabular}{ccccc}
\hline \multirow{2}{*}{ Ranking } & \multicolumn{4}{c}{ Fish species } \\
\cline { 2 - 5 } & Control & Yellow pike conger & Featherback & Red snapper \\
\hline 1 & 8 & 7 & 4 & 1 \\
2 & 6 & 8 & 6 & 0 \\
3 & 4 & 3 & 7 & 6 \\
4 & 2 & 2 & 3 & 13 \\
\hline \hline
\end{tabular}

Skor tertinggi kerenyahan kerupuk adalah 6,58 dari kerupuk tanpa ikan sama dengan skor ikan remang 6,58, skor ikan belida 5,16 dan skor terendah adalah kerupuk ikan kakap yaitu 1,68 . Skor kerupuk yang diinginkan adalah yang berada di atas nilai 5,0 baik nilai kerenyahan secara rating maupun kerenyahan secara peringkat. Dengan demikian kerupuk ikan remang menghasilkan kerupuk dengan kerenyahan paling tinggi. Hasil perhitungan kerenyahan kerupuk secara peringkat dengan analisis baku komposit disajikan dalam Appendix 1.

Pengaruh persentase ikan terhadap kerenyahan kerupuk goreng (Table 7) menunjukkan bahwa peningkatan persentase ikan menurunkan kerenyahan kerupuk. Kerenyahan tertinggi secara rating diperoleh pada kontrol dengan nilai kerenyahan 6,85 diikuti oleh persentase ikan $25 \%, 40 \%$ dan $50 \%$ dengan nilai kerenyahan berturut-turut 6,$65 ; 5,85$; dan 5,45 yang secara statistik memperlihatkan perbedaan nyata untuk setiap peningkatan persentase ikan. Penurunan nilai kerenyahan sejalan dengan penurunan volume pengembangan kerupuk.

Hasil pengukuran kerenyahan secara rating terhadap pengaruh konsentrasi ikan remang disajikan pada Table 8. Bila dibandingkan hasil uji kerenyahan kerupuk goreng secara rating dengan secara peringkat nampak uji peringkat lebih tajam dibandingkan dari uji kerenyahan secara rating. 
Table 7. Mean values of volumetric expansion and crispiness of fish crackers obtained from scoring and ranking test

\begin{tabular}{cccc}
\hline \multirow{2}{*}{ Fisb percentage } & Volumetric expansion & \multicolumn{2}{c}{ Crispiness } \\
\cline { 3 - 4 } & $(\%)$ & scoring & ranking \\
\hline 0 & $374^{a}$ & $6.85^{a}$ & 7.09 \\
25 & $275^{b}$ & $6.65^{b}$ & 6.88 \\
40 & $255^{c}$ & $5.85^{c}$ & 3.12 \\
50 & $244^{c}$ & $5.45^{d}$ & 2.91 \\
\hline \hline
\end{tabular}

Note: The same notation indicates statistically not different $(P>0.05)$

Table 8. Influence of yellow pike conger percentage on fish cracker crispiness

\begin{tabular}{ccccc}
\hline \multirow{2}{*}{ Ranking } & \multicolumn{4}{c}{ Fish percentage (\%) } \\
\cline { 2 - 5 } & 0 & 25 & 40 & 50 \\
\hline 1 & 7 & 7 & 3 & 3 \\
2 & 8 & 7 & 2 & 3 \\
3 & 3 & 4 & 8 & 5 \\
4 & 2 & 2 & 7 & 9 \\
\hline \hline
\end{tabular}

Dari hasil uji peringkat nilai kerenyahan kerupuk dengan persentase $\mathbf{2 5} \%$ adalah 6,88 tidak berbeda dengan kontrol dengan nilai kerenyahan 7,09 , tapi sangat jauh berbeda dengan perlakuan pemberian ikan $40 \%$ dan $50 \%$ dengan kerenyahan 3,12 dan 2,91. Hasil perhitungan dengan analisis baku komposit disajikan pada Appendix 2.

Kerenyahan kerupuk yang diharapkan baik secara rating maupun secara peringkat adalah 5,0. Dari hasil uji rating semua perlakuan memberikan nilai kerenyahan yang diharapkan, namun pada hasil uji peringkat kerenyahan kerupuk yang diharapkan dihasilkan dari kerupuk goreng dengan pemberian ikan dengan persentase $\mathbf{2 5} \%$. Dengan demikian dapat dikatakan pemberian ikan dengan persentase $25 \%$ terhadap tepung sagu memberikan nilai kerenyahan yang terbaik. 


\section{Rasa Ikan}

Pengujian ada atau tidaknya rasa ikan pada kerupuk dilakukan dengan uji rangsangan tunggal (Soekarto, 1982), datanya disajikan pada Table 9. Sedangkan intensitas rasa ikan pada kerupuk goreng diuji secara rating yang datanya disajikan pada Table 10. Kerupuk tanpa pemberian ikan dinyatakan oleh 15 orang tidak berasa ikan dan 5 orang menyatakan adanya rasa ikan. Penambahan ikan $25 \%$ pada adonan dinyatakan berasa ikan oleh 19 orang panelis dan 1 orang menyatakan tidak berasa ikan. Penambahan $40 \%$ dan $50 \%$ ikan, semua panelis menyatakan sudah merasakan adanya rasa ikan pada kerupuk.

Table 9. Influence of presentage of yellow pike conger on the crackers taste used single stimulus test

\begin{tabular}{ccccc}
\hline \multirow{2}{*}{ Judgement } & \multicolumn{4}{c}{ Fish Percentage } \\
\cline { 2 - 5 } & 0 & 25 & 40 & 50 \\
\hline 1 & 0 & 1 & 1 & 1 \\
2 & 0 & 1 & 1 & 1 \\
3 & 0 & 1 & 1 & 1 \\
4 & 0 & 1 & 1 & 1 \\
5 & 0 & 1 & 1 & 1 \\
6 & 1 & 1 & 1 & 1 \\
7 & 1 & 1 & 1 & 1 \\
8 & 0 & 1 & 1 & 1 \\
9 & 0 & 1 & 1 & 1 \\
10 & 1 & 1 & 1 & 1 \\
11 & 1 & 0 & 1 & 1 \\
12 & 0 & 1 & 1 & 1 \\
13 & 0 & 1 & 1 & 1 \\
14 & 0 & 1 & 1 & 1 \\
15 & 0 & 1 & 1 & 1 \\
16 & 0 & 1 & 1 & 1 \\
17 & 1 & 1 & 1 & 1 \\
18 & 0 & 1 & 1 & 1 \\
19 & 0 & 1 & 1 & 1 \\
20 & 0 & 1 & 1 & 1 \\
\hline Total & 5 & $19 * * * * * * *$ & $20 * *$ \\
\hline \hline
\end{tabular}

Note: $\quad 0=$ fish taste not detected; $1=$ fish taste detected

** $15-17$ significantly different $P>0.05$ and $P>0.01$ 
Table 10. Influence of yellow pike conger persentage on crackers taste using score test from 20 judgement

\begin{tabular}{ccccc}
\hline \multirow{2}{*}{ Judgement } & \multicolumn{4}{c}{ Fish percentage } \\
\cline { 2 - 5 } & 0 & 25 & 40 & 50 \\
\hline 1 & 0 & 2 & 4 & 3 \\
2 & 0 & 3 & 3 & 4 \\
3 & 0 & 3 & 2 & 4 \\
4 & 0 & 3 & 2 & 5 \\
5 & 0 & 3 & 2 & 3 \\
6 & 1 & 2 & 3 & 4 \\
7 & 1 & 3 & 3 & 4 \\
8 & 0 & 3 & 4 & 3 \\
9 & 0 & 4 & 3 & 4 \\
10 & 2 & 3 & 4 & 3 \\
11 & 4 & 0 & 4 & 4 \\
12 & 0 & 3 & 4 & 5 \\
13 & 0 & 3 & 5 & 4 \\
14 & 0 & 1 & 3 & 5 \\
15 & 0 & 1 & 4 & 3 \\
16 & 0 & 3 & 3 & 3 \\
17 & 3 & 3 & 4 & 4 \\
18 & 0 & 2 & 3 & 4 \\
19 & 0 & 3 & 4 & 5 \\
20 & 0 & 3 & 4 & 4 \\
\hline Total & 11 & 51 & 69 & 78 \\
\hline Mean & 0.6 & 2.6 & 3.5 & 3.9 \\
\hline
\end{tabular}

Note: $\quad 5=$ very strong, $4=$ strong, $3=$ slightly strong 2 = soft, 1 = very soft

Pengaruh penambahan persentase ikan pada adonan dalam pembuatan kerupuk sebesar $0 ; 25 \%$; $40 \%$ dan $50 \%$ memberikan intensitas rasa ikan berturut-turut adalah 0,$6 ; 2,6 ; 3,5 ;$ dan 3,9 . Intensitas rasa 0,6 menyatakan rasa ikan pada kerupuk sangat lemah, 2,6 rasa ikan terletak antara lemah dengan agak kuat, 3,5 berarti rasa ikan cukup kuat dan 3,9 berarti rasa ikan pada kerupuk goreng kuat. Dengan demikian kerupuk ikan remang pada persentase ikan $25 \%$ sudah memberikan rasa ikan. Bila dihubungkan dengan standar kandungan protein krupuk menurut SII $0272-90$ sebesar 5\% (SII, 1990) maka persentase ikan sebesar $25 \%$ dengan kandungan protein $5,08 \%$ sudah memenuhi persyaratan mutu kerupuk. 


\section{KESIMPULAN}

Dari ketiga jenis ikan yang digunakan dalam penelitian serta konsentrasi penambahan ikan, maka ikan remang (Congresox talabon) pada persentase $25 \%$ memberikan pengembangan dan nilai kerenyahan tertinggi. Ikan belida (Notopterus chilatus) memberikan volume pengembangan terkecil dengan nilai kerenyahan di bawah ikan remang, sedangkan ikan kakap (Lates calcarifer) volume pengembangannya lebih tinggi dari ikan belida, tetapi kerenyahannya lebih rendah.

Intensitas rasa ikan pada kerupuk semakin tinggi dengan meningkatnya konsentrasi penambahan daging ikan tetapi menurunkan volume pengembangan dan kerenyahan kerupuk.

\section{DAFTAR PUSTAKA}

AOAC. 1984. Official Method of Analysis. Official Chemist, Washington DC.

Cecil, J.E., G. Lau, S.H. Heng dan C.K. Ku. 1982. The sago starch industry. A technical profile based on preliminary study made in Serawak. Trop. Prod. Inst. (L 58) : 56 -62. London.

Hodge, J.E. dan E.M. Osman. 1976. Carbohydrate in O.R. Fennema, 2 (ed). Principles of food science part I, food chemistry. Marcel dekker Inc., New York.

Matz, S.A. 1984. Snack food technology. 2nd ed. Publishing Co. Inc., Westport, Connecticut.

Muliawan, D. 1991. Pengaruh berbagai tingkat kadar air terhadap pengembangan kerupuk sagu goreng. Skripsi. Jurusan teknologi Industri, FATETA, IPB, Bogor.

SII. 1990.Standar Industri Kerupuk. Departemen Perindustrian, RI.

Soekarto, S.T. 1985. Penilaian organoleptik. Bharata Karya Aksara, Jakarta.

Soekarto, S.T. dan D. Muliawan. 1991. Volumetric expansion of Indonesian chips (kerupuk) during oil deep frying as affected by states of bound water. Proc. $3^{\text {rd }}$ Seminar. JICA-IPN on Agricultural Engineering and Technology, Bogor.

Wiriano, H. 1984. Mekanisasi dan teknologi pembuatan kerupuk. Balai Pengembangan Makanan dan Phytokimia. Badan Penelitian dan Pengembangan Industri, Departemen Perindustrian.

Yu, S.Y., J.R. Mitchell dan A. Abdullah. 1981. Production and acceptibility testing of fish crackers (keropok) prepared by extrusion method. J. Food technol. $16: 51-59$. 
Yu, S.Y. 1991. Acceptibility of fish crackers (Keropok) made from different types of flour. Asean Food Journal. 6 (3): 114 - 116.

Zulviani, R. 1992. Mempelajari pengaruh berbagai tingkat suhu penggorengan terhadap pengembangan kerupuk sagu goreng. Skripsi. Jurusan TPG. Fakultas Teknologi Pertanian, IPB, Bogor. 
Appendix 1. Result of crackers crispiness ranking on the fish meat species using composite standard analysis

\begin{tabular}{|c|c|c|c|c|c|}
\hline \multirow[b]{2}{*}{$r_{i}$} & \multirow[b]{2}{*}{$R 1$} & \multicolumn{4}{|c|}{ Fish Species } \\
\hline & & Control & $\begin{array}{c}\text { Yellow } \\
\text { pike } \\
\text { conger }\end{array}$ & $\begin{array}{c}\text { Featber } \\
\text { back }\end{array}$ & $\begin{array}{c}\text { Red } \\
\text { snapper }\end{array}$ \\
\hline 1 & 4 & 32 & 28 & 16 & 4 \\
\hline 2 & 3 & 18 & 24 & 18 & 0 \\
\hline 3 & 2 & 8 & 6 & 14 & 12 \\
\hline 4 & 1 & 2 & 2 & 3 & 13 \\
\hline$f_{i} R_{i}$ & & 60 & 60 & 51 & 29 \\
\hline$N$ & & 20 & 20 & 20 & 20 \\
\hline$C_{j}>C$ & & 50 & 50 & 41 & 19 \\
\hline $\begin{array}{l}P_{j}>C \\
P_{j}=0.5\end{array}$ & & 0.625 & 0.625 & 0.5125 & 0.2375 \\
\hline $\begin{array}{c}c_{j}=0.1584 \\
Z_{j} \\
R_{j}\end{array}$ & & & & & \\
\hline$R_{j}=1.6572$ & & 0.789 & 0.789 & 0.0789 & -1.6572 \\
\hline$c_{R}=0.9997$ & & 2.4463 & 2.4463 & 1.7361 & 0 \\
\hline$R_{c}$ & & 6.5787 & 6.5786 & 5.1578 & 1.6846 \\
\hline
\end{tabular}

Remark $: r_{i}=$ ranking 
Appendix 2. Result of crackers crispiness ranking on the fish meat species concentration using composite standard analysis

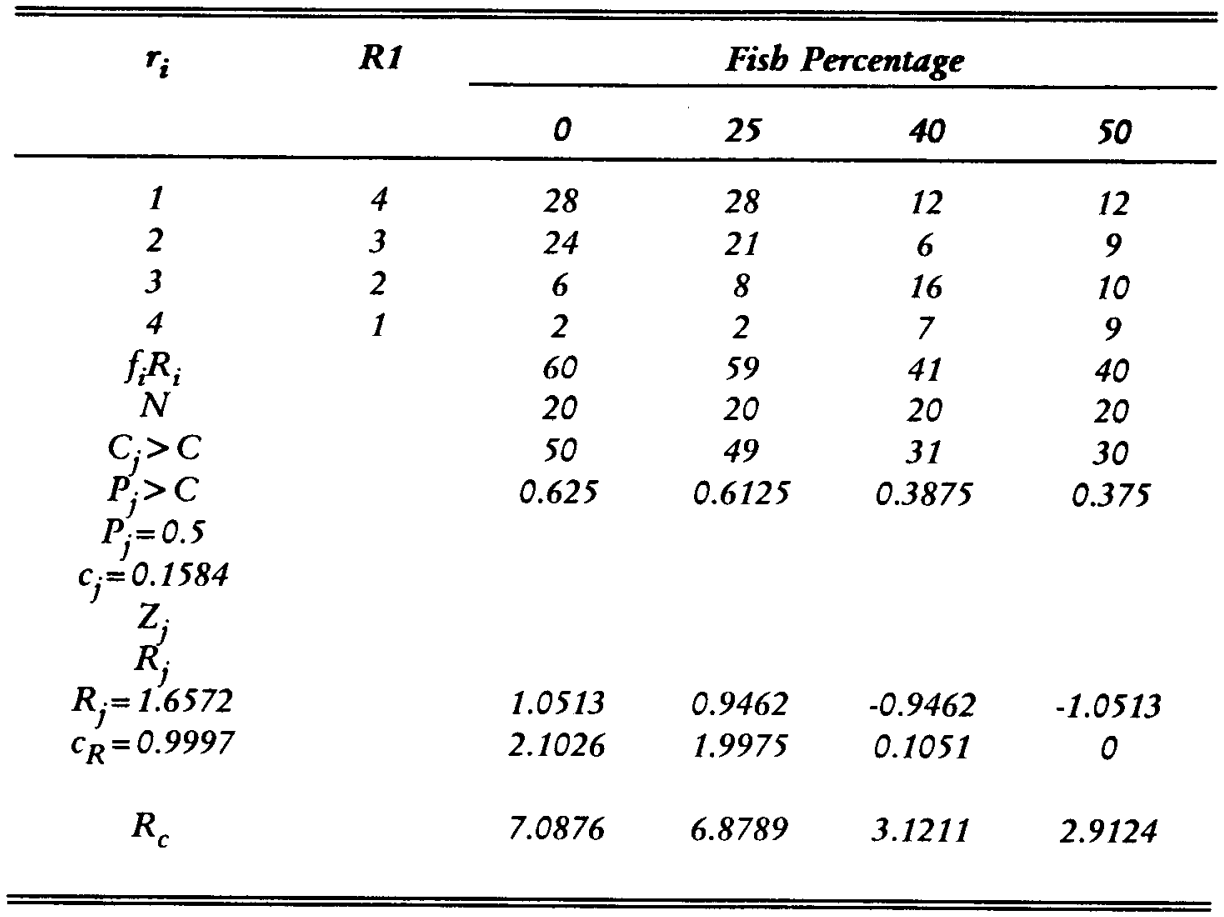

Remark $: r_{i}=$ ranking 